\title{
Occurrence and epidemiological aspects of potato silver scurf in California
}

\author{
Marcos G. Cunha ${ }^{1}$; David M. Rizzo ${ }^{2}$ \\ ${ }^{1}$ UFG, Esc. Agronomia e Eng. Alimentos, C. Postal 131, 74001-970 Goiânia-GO; ²University of California, Department of Plant \\ Pathology, Davis, CA 95616, USA
}

\begin{abstract}
A new potato tuber disease has been observed in the Tulelake region, California, USA, since 1995, with tuber symptoms suggestive of silver scurf disease (Helminthosporium solani). In this work we isolated, identified and demonstrated the nature of the causal agent of this potato disease in California. In addition, the distribution of $H$. solani in potato fields and the inoculum potential at harvest time were investigated. Disease progress and $H$. solani spore populations were also characterised under commercial storage conditions. The main fungal genera associated with potato tubers in storage were Helminthosporium solani, Colletotrichum sp., Fusarium sp., and Rhizoctonia sp. The results of Koch's postulates indicated that $H$. solani is responsible for the outbreak of silver scurf in the Tulelake region. In a disease survey in three commercial potato fields naturally infested, $H$. solani infections occurred in all fields. However, the extension of the infections differed significantly between the fields. During potato storage, silver scurf usually increased over time. The percentage of the tuber surface covered by silver scurf varied from $3.5 \%$ up to $35.5 \%$ during the storage period. The number of $H$. solani lesions per tuber also progressively increased from $6 \%$ up to $35 \%$, six months after storage. $H$. solani spore populations also increased over time in all studied potato stores; nevertheless, they followed no consistent pattern, exhibiting multiple and variable peaks of increase and reduction during the period of storage.
\end{abstract}

Keywords: Solanum tuberosum, Helminthosporium solani, Disease progress, post-harvest disease, potato tuber disease, spore population.

\section{(Recebido para publicação em 18 de novembro de 2003 e aceito em 26 de outubro de 2004)}

$\mathrm{I}_{\mathrm{s}}^{\mathrm{n}}$ potato (Solanum tuberosum L.), urface blemishing tuber diseases have assumed great importance with the development of washing and prepacking of potatoes. Silver scurf, caused by Helminthosporium solani Dur. \& Mont. (1849), is one disease that often adversely affects the appearance and skin color of potato tubers, resulting in reduced consumer acceptance (Secor \& Gudmestad, 1999). It is considered a problem of storage potatoes even though infection often takes place before harvest (Jellis \& Taylor, 1977; Lennard, 1980). Irregular lesions expand over the tuber surface and often become sooty due to the presence of large numbers of conidiophores and conidia that arise between peridermal cells. $H$. solani colonization is usually limited to periderm and cortex cells; nevertheless, cell death in these layers can cause water loss from tuber medullary cells, which ultimately can compromise tuber weight and consistency. Old lesions frequently exhibit a silvery appearance when they are wet (Hunger \& McIntyre, 1979; Heiny \& McIntyre, 1983; Firman \& Allen, 1995).

$H$. solani is generally disseminated by infected seed tubers. It is well documented that infected tubers play an important role as primary inoculum in potato fields, but uncertainty persists as to whether they are the only source of inoculum. Due to a lack of tangible 
evidence, early reports put forward the idea that $H$. solani was unable to survive in soil (Jellis \& Taylor, 1977; Firman \& Allien, 1995). Recent results have indicated that $H$. solani somehow persists in soil and also serves as a primary inoculum source. Merida \& Loria (1994) demonstrated that $H$. solani overwintered in naturally infested soil for at least one year. Bains et al. (1996) also observed pathogen free seed-tubers infected by $H$. solani in fields that had been free of potato crops for up to four years. Therefore, it is very likely that both seed and soil-borne inocula play important roles in silver scurf outbreaks.

Severe silver scurf attacks are highly dependent on storage conditions. Lennard (1980) demonstrated that the development of silver scurf was limited in a dry atmosphere at any temperature. However, at high humidity, the disease increased with increasing temperature above $5^{\circ} \mathrm{C}$. According to Hooker (1981), the minimum conditions for infection are $3^{\circ} \mathrm{C}$ and $90 \%$ relative humidity. These observations strongly support the view that $H$. solani may complete several disease cycles if storage conditions, especially temperature and relative humidity, are permissive.

Located in the far north of California, Tulelake is primarily an agricultural district. The potato is the most important commodity since its output is about $50 \%$ of the total annual production value (Danosky, 1995). Approximately eight years ago, potato growers reported a new potato tuber disease in the Tulelake region. The incidence of this disease has increased annually and in some potato sheds up to $80 \%$ of stored tubers may be affected by this surface malady. Initially, isolations recovered mostly Colletotrichum sp., but symptoms suggested silver scurf (Davis, R.M., University of California, Davis, personal communication). The objectives of this work were to isolate, identify and demonstrate the nature of the causal agent of this new potato disease in California. Because the management of this disease involves several control measures, the distribution of $H$. solani in potato fields and the inoculum potential at harvest time were investigated. In addition, disease progress and $H$. solani spore populations were characterised under commercial storage conditions.

\section{MATERIAL AND METHODS}

\section{Sampling, isolation identification of the pathogen}

During June 1997, potato tubers were arbitrarly collected from three commercial sheds and one packaging plant in Tulelake. Isolations were made by two different approaches. 1) After washing infected tubers, tissue fragments were taken from lesion margins, disinfested in $5 \% \mathrm{NaOCl}$ for 3 minutes, dried on sterile paper towel and placed on either clarified V8 juice agar medium (Dhingra \& Sinclair, 1995) amended with $20 \mathrm{ml} / \mathrm{L}$ of $0.25 \%$ streptomycin sulfate, or potato dextrose agar (PDA, Difco) amended with $0.25 \%$ streptomycin sulfate. The plates were incubated at $25^{\circ} \mathrm{C}$ in the dark and examined every other day; 2) infected tubers were washed, disinfested in $2.5 \%$ $\mathrm{NaOCl}$ for 3 minutes, dried and incubated at $16^{\circ} \mathrm{C}$ in the dark at high relative humidity (>90\%) for 15 to 20 days. Using a stereoscopic microscope, fungal structures produced on lesions from infected tubers were excised and placed into a small amount of antibiotic solution $(0.25 \%$ streptomycin sulfate) on water-agar medium in Petri plates. Plates were manually agitated to disperse fungal spores on the agar surface, and then incubated at $25^{\circ} \mathrm{C}$ in the dark for 4 to 6 days. Using a stereoscopic microscope, single germinated spores or hyphal tips of single spore colonies were transferred to plates with clarified V8 juice agar amended with $20 \mathrm{ml} / \mathrm{L}$ of $0.25 \%$ streptomycin sulfate, and incubated as above for 30 days. Fungal isolates produced by both approaches were maintained on either clarified V8 juice agar or potato dextrose agar (PDA) at $5^{\circ} \mathrm{C}$.

\section{Koch's Postulates}

Inoculation tests were carried out to determine the causal agent of this disease. Mature detached tubers of cultivar Russet Burbank were inoculated with either Colletotrichum sp. or $H$. solani isolates. Disease-free tubers were washed, surface disinfested in 5\% $\mathrm{NaOCl}$ for 5 minutes, rinsed in sterile distilled water and dried. Using handheld pump sprayers (Airspray ${ }^{\mathrm{TM}}$, Tech Spray, Inc., Peachtree City, GA), tubers were sprayed until runoff with spore suspensions of approximately $10^{5}$ spores/ ml. Control tubers were sprayed with tween-water solution. Inoculated tubers were placed in plastic crispers $(0.3 \times 0.23 \times 0.10 \mathrm{~m})$ and incubated at $16^{\circ} \mathrm{C}$ at high relative humidity ( $>90 \%$ ) for 30 days. The experimental design was entirely random with five replicates per treatment. Each replicate had five potato tubers. Symptoms were visually evaluated and the number of sporulating lesions per tuber recorded. Using the second isolation approach, previously outlined, reisolations were performed on each treatment replica. Descriptive statistical analysis was performed using SPSS 10.0 software (SPSS Inc., Chicago, IL). This assay was repeated twice.

\section{time \\ Silver scurf incidence at harvest}

To study the contribution of $H$. solani field infections on later silver scurf development during storage and the distribution of infection sites within potato fields, 108 samples were collected one week before harvest in three geographically separated fields in Tulelake. Potatoes were not raised in any fields in the previous three years, but silver scurf was thought to have previously occurred on potato crops in these fields (Kirby, D., Intermountain Research \& Extension Center, Tulelake, CA, personal communication). Each sample consisted of a single plant and all its tubers. Tubers were kept at $5^{\circ} \mathrm{C}$ until they were washed, disinfested in $2.5 \% \mathrm{NaOCl}$ for 3 minutes and dried. They were placed in plastic crispers $(0.3 \times 0.23 \times 0.10 \mathrm{~m})$ and incubated at $15^{\circ} \mathrm{C}$ and high humidity (>90\%) in the dark for 30 days. Due to lack of a specific diagrammatic scale for scoring silver scurf on tubers (Adams et al., 1985; Firman \& Allen, 1995; Frazier et al., 1998; Rodriguez et al., 1996), disease severity was visually evaluated by estimating the percentage of infected surface area of the tubers, regarding sporulating lesions only. In addition, the number of sporulating lesions per tuber was counted and disease incidence determined by calculating the 
Table 1. Description of commercial storage of table stock potatoes. Tulelake, CA, USA, 1997.

\begin{tabular}{lcccccc}
\hline Sheds & $\begin{array}{c}\text { Potato } \\
\text { stored } \\
\text { (ton) }\end{array}$ & $\begin{array}{c}\text { Relative } \\
\text { humidity } \\
(\%)\end{array}$ & $\begin{array}{c}\text { Temperature } \\
\left({ }^{\circ} \mathrm{C}\right)\end{array}$ & $\begin{array}{c}\text { Wind } \\
\text { speed } \\
(\mathbf{m p h})\end{array}$ & $\begin{array}{c}\text { Ventilation } \\
\text { system } \\
\text { (h/day) }\end{array}$ & $\begin{array}{c}\text { Ozone } \\
\text { spray }\end{array}$ \\
\hline 1 & 4,082 & $\sim 90^{\mathrm{a}}$ & $4.5-6.0$ & $2-5$ & natural & - \\
2 & 3,175 & 91 & 5.0 & 5 & $7-11^{\mathrm{c}}$ & - \\
3 & 4,082 & $\sim 90$ & $4.5-6.0$ & - & natural & - \\
4 & 4,762 & 95 & 4.0 & 5 & $7-11$ & 1 \\
5 & 2,177 & 85 & 6.0 & - & $7-11$ & - \\
\hline
\end{tabular}

${ }^{\mathrm{a} N o}$ control of relative humidity; ${ }^{\mathrm{b}}$ No control of air coming in and out of the sheds, after cooling down the potato pile temperature at the beginning of the storage period; ${ }^{\circ} F a n s$ ran for 10-11 hours/day at the beginning of storage period, then 7-8 hours/day to maintain the temperature.

Table 2. Incidence of silver scurf caused by Helminthosporium solani at harvest time in three potato fields in Tulelake, CA, USA, 1997.

\begin{tabular}{lcccc}
\hline Potato Fields & $\begin{array}{c}\text { Tubers per } \\
\text { plant }\end{array}$ & \multicolumn{3}{c}{ Infection indices } \\
\cline { 3 - 5 } & $11.2 \pm 0.36 \mathrm{ab}$ & $100.0 \pm 0.00 \mathrm{ab}$ & $4.5 \pm 0.23 \mathrm{ab}$ & $2.1 \pm 0.30 \mathrm{ab}$ \\
infected plant \%) $^{\text {Incidence }}$ & $\begin{array}{c}\text { Infected tubers } \\
\text { per sample }\end{array}$ & $\begin{array}{c}\text { Lesions per } \\
\text { tuber }\end{array}$ \\
\hline 1 & $11.5 \pm 0.37 \mathrm{a}$ & $72.2 \pm 7.57 \mathrm{~b}$ & $2.2 \pm 0.31 \mathrm{~b}$ & $0.6 \pm 0.12 \mathrm{~b}$ \\
2 & $11.1 \pm 0.44 \mathrm{a}$ & $69.4 \pm 7.78 \mathrm{~b}$ & $1.5 \pm 0.23 \mathrm{~b}$ & $0.4 \pm 0.10 \mathrm{~b}$ \\
\hline Total & $11.3 \pm 0.22$ & $80.5 \pm 3.83$ & $2.7 \pm 0.19$ & $1.0 \pm 0.14$ \\
\hline
\end{tabular}

${ }^{\text {aPercentage of plants with at least one infected tuber; }{ }^{\mathrm{b}} \text { Means } \pm \text { Standard error }(\mathrm{n}=36) \text { followed }}$ by different letters in the same column differ significantly at $\mathrm{p}=0.05$.

percentage of plants with at least one infected tuber. Analysis of variance and comparisons of means were carried out with the SPSS 10.0 software.

Development of silver scurf in commercial sheds

This trial was conducted at five commercial potato sheds in Tulelake, during 1997/1998 (Table 1). Before planting, all potato seeds were treated with thiophanate-methyl $(2.5 \%$ a.i., Tops 2.5D®; Haco, Inc. Madison, WI) as recommended by the manufacturer. Each shed was filled with tubers of Russet Burbank, harvested in several potato fields in Tulelake. The loading period ranged from $29 / 9$ to $8 / 10 / 97$. After a curing period, 30 tubers were arbitrary collected from each shed every 15 days. Sub samples of 20 tubers were washed, disinfested, and incubated as previously described. Disease incidence and severity were evaluated in the same manner as outlined in the previous experiment.

Spore populations of $H$. solani were monitored during the storage period. Spore traps (Rotorod sampler, model 20, Sampling Technology, Inc.) were set up in each shed and run at a constant speed for 24 hours every 15 days. Spore traps were always placed on the top of piled potatoes close to the center of the potato sheds. H. solani spores trapped by the trap rods were individually counted using a microscope at 100x magnification lens and the average of spores per trap rod was determined. The number of spores per cubic meter of air was calculated following manufacturer guidelines (Anonymous, 1997). Descriptive statistical analysis was performed using SPSS 10.0 software.

\section{RESULTS AND DISCUSSION}

Sampling, isolation and identification of the pathogen

After washing, the majority of potato tubers showed scattered dark blemishes that were limited to the tuber periderm. No signs of any pathogen were observed by microscopic examinations of lesions. Scattered $H$. solani lesions usually sporulated after incubation at $15^{\circ} \mathrm{C}$ for three weeks at high humidity $(>90 \%)$. Dark masses of conidiophores and conidia were observed between peridermal cells with the unaided eye. These lesions often coalesced giving rise to a larger affected tuber surface, especially at the stolon end.

Fungal isolates were identified based on their morphologic features (Ellis, 1968; Ellis, 1976; Alcorn, 1988; Barnett \& Hunter, 1988; Alexopoulos et al., 1996). The main fungal genera associated with potato tubers were $H$. solani, Colletotrichum sp., Fusarium sp., and Rhizoctonia sp.

Placing fragments of infected tubers on either clarified V8 juice agar or PDA was ineffective in isolating $H$. solani. This approach yielded several Colletotrichum isolates, a few Fusarium and Rhizoctonia isolates and a great number of unidentified fungal isolates. Allowing $H$. solani to sporulate on the tuber surface and then transferring its spores to clarified V8 juice agar was very effective in isolating $H$. solani. This method yielded a few Rhizoctonia isolates and a great number of $H$. solani isolates. By this approach, H. solani isolates could be frequently collected from almost every infected potato tuber since they usually displayed multiple sporulating infection sites.

The two most common fungi isolated in the survey were $H$. solani and Colletotrichum sp., which were used in a series of inoculation tests for determining the causal agent of this potato-tuber disease. Neither tubers sprayed with tween-water solution nor those inoculated with Colletotrichum sp. developed any kind of blemishes on tuber surface, and none of them yielded any fungal isolates after the incubation period. Conversely, H. solani successfully infected mature detached tubers, which displayed an average of 27.9 (se=2.1, s=9.3, $\mathrm{n}=20$ ) lesions per tuber. This fungus also gave rise to symptoms similar to those observed on infected tubers from the Tulelake area. Scattered lesions were initially whitish and then silvery as they aged. Black tufts of $H$. solani conidia and conidiophores developed regularly among peridermal cells of the colonized tuber surface.

Although it has been observed in several other potato growing areas across USA, this is the first report of $H$. solani in California. The completion of Koch's postulates indicated that $H$. solani is the fungus responsible for the 
tuber-borne disease that has recently threatened potato production in Tulelake. It is generally regarded as a minor potato problem. Nevertheless, severe outbreaks have frequently occurred in recent years in North America (Jeger et al., 1996; Secor \& Gudmestad, 1999). It is argued that these outbreaks are the consequence of the rise of $H$. solani populations insensitive to thiophanate-methyl fungicide that has been frequently applied for controlling dry rot (Fusarium solani) and other diseases of potato seed tubers (Merida \& Loria, 1994b; Secor \& Gudmestad, 1999; Errampalli et al. 2001; Cunha \& Rizzo, 2003).

Initial studies of the disease in California showed conflicting results (Davis, R.M., University of California, Davis, personal communication). It seems that the earlier studies employed an isolation approach in which infected tissue was washed, disinfested, placed on artificial medium and incubated at $25^{\circ} \mathrm{C}$. This approach, which is one of the most commonly employed to isolate fungi associated with diseased plants, was found to be unfavourable for recovery of $H$. solani, which is readily overgrown by other pathogens, saprophytes or even endophytes. In addition, $H$. solani is a very slow growing fungus that usually requires 4 to 5 weeks to grow 3.5 to $4.5 \mathrm{~cm}$ diameter on clarified V8 juice medium (Merida \& Loria, 1994; Elson et al., 1998). Therefore, successful approaches for isolating $H$. solani should not only encourage $H$. solani growth but also adversely affect other organisms associated with infected tissue. The second isolation approach used in this work usually yielded $H$. solani isolates regardless of infection levels. Thus, it is a reliable approach for diagnosis of silver scurf.

\section{time}

Silver scurf incidence at harvest

The number of progeny tubers per plant did not differ between fields, with a mean of 11 tubers/plant (Table 2). $H$. solani infections occurred in all studied potato fields, however, the extent differed significantly between fields (Table 2). Based on all infection indices, infection on progeny tubers from field 1 was significantly greater $(\mathrm{p}=0.05)$ than on tubers from the other fields. The incidence of $H$. solani on plants from
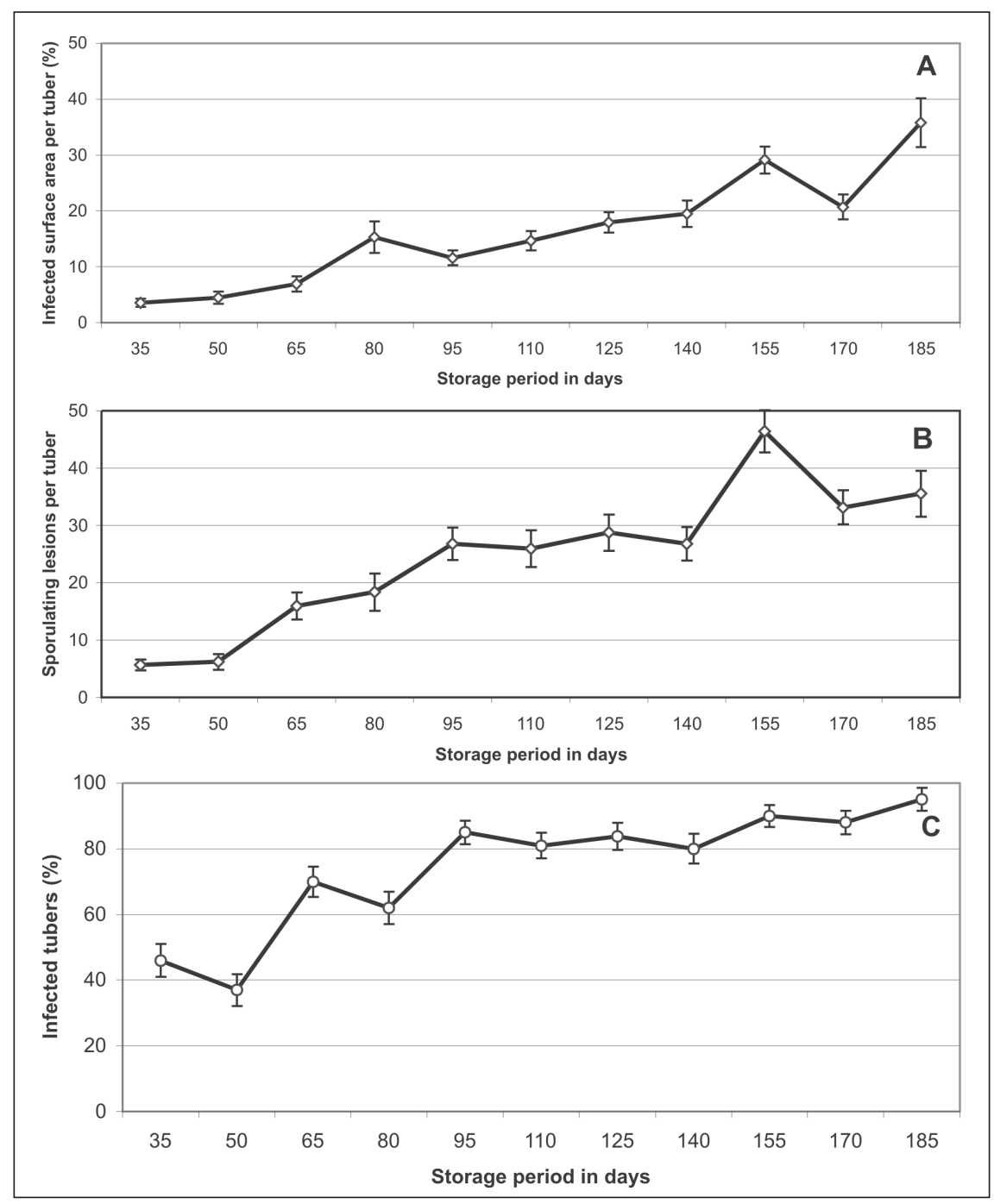

Figure 1. Development of silver scurf caused by Helminthosporium solani in five commercial potato sheds in Tulelake, CA, 1997/98. Disease severity was assessed by the percentage of tuber area covered with sporulating lesions (A) and by the number of sporulating lesions on tubers (B). Incidence is represented as the percentage of infected tubers (C). Vertical bars show the standard error of the mean $(n=100$ in observations 35 to $110 ; n=80$ in observations 125 to 170 and $n=40$ in observation 185). Tulelake, CA, USA, 1997.

field 1 was $100 \%$ (i.e., all sampled plants had at least one infected tuber). Incidence in other fields was approximately $70 \%$ (Table 2). The mean number of infected tubers was 4.5 among progeny tubers from plants of field 1 , while it was approximately 2.2 from plants from the other fields. Regarding $H$. solani lesions, the mean number of lesions per tuber from field 1 was 2.1 and less than 0.6 on tubers from the other fields.

Even though infestation varied significantly between fields, the number of progeny tubers per plant was nearly the same in all fields (Table 2). These observations agree with the idea that silver scurf does not cause yield losses at harvest (Secor \& Gudmestad, 1999). Frazier et al.(1998), likewise, observed on either naturally or artificially inoculated potato seed tubers that plant emergence and populations were not affected by $H$. solani infection. It has been well documented that $H$. solani is (Heiny \& McIntyre, 1983). Thus, it seems that most tuber resources are still safe and available for supporting sprout emergence, initial vegetative growth, and plants which develop therefrom are sufficiently vigorous to avoid any significant reduction in productivity.

At harvest time, silver scurf incidence in potato plants from Tulelake always confined to the tuber periderm 


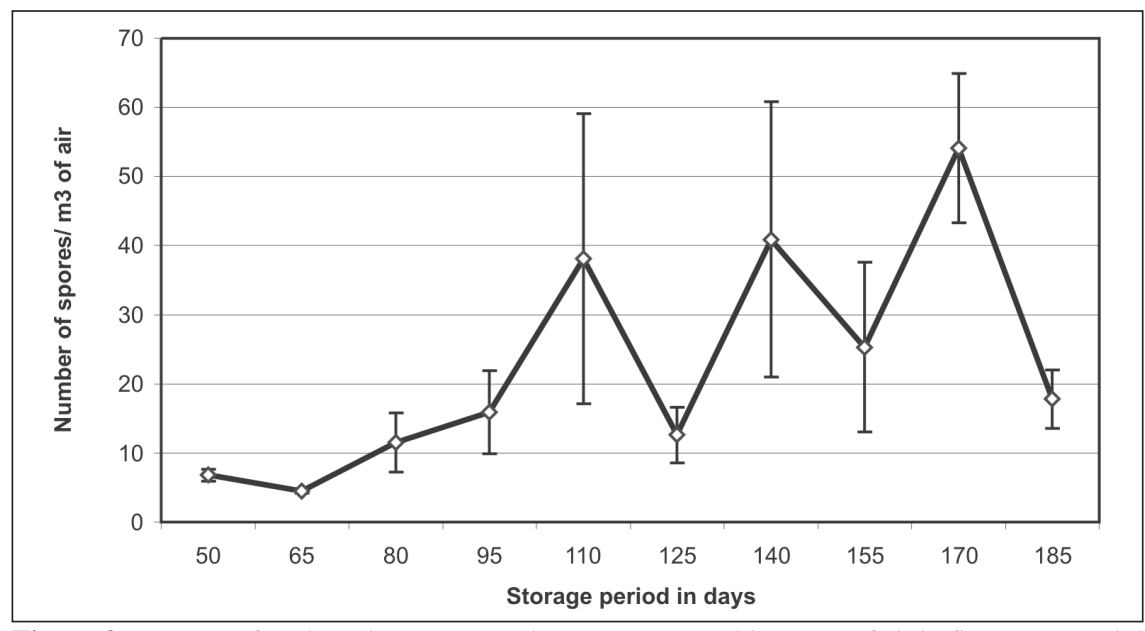

Figure 3. Average of Helminthosporium solani spores per cubic meter of air in five commercial potato sheds in Tulelake, CA, 1997/98. Incidence is represented as the percentage of infected tubers. Vertical bars show the standard error of the mean $(n=10$ in observations 50 to $110 ; n=8$ in observations 125 to 170 and $n=4$ in observation 185). Tulelake, CA, USA, 1997.

was relatively high, but the number of infected tubers per plant along with the number of lesions per tuber was quite the reverse at all studied fields (Table 2). This low infection level is very unlikely to compromise potato quality at harvest time but it will serve as a large and efficient amount of inoculum just waiting for the suitable conditions that usually occur in storage sheds to develop into a post-harvest epidemic.

Following three years without potato production, infestation and distribution of $H$. solani in a subsequent crop varied significantly between potato fields (Table 2). These findings suggest that, if $H$. solani is able to survive in the absence of its host, it may occur for a limited period of time, especially under favourable conditions. One can not rule out the possibility that potato seed tubers sowed in each field had different levels of initial $H$. solani inoculum. To confirm the magnitude of the effect of crop rotation on $H$. solani survival will require temporal studies of $H$. solani infestation, which was beyond the scope of this work.

\section{Development of silver scurf in} commercial sheds

Disease severity and incidence (Figure 1) were used to determine silver scurf development under conditions found within commercial potato sheds. Evaluations began on the $35^{\text {th }}$ storage day. Regardless of potato storage conditions or disease evaluation methods, silver scurf generally increased over time in all potato sheds. The percentage of tuber surface covered by silver scurf blemishes gradually varied from $3.5 \%$ up to $35.5 \%$ during the storage period. An identical pattern was depicted by the number of $H$. solani lesions per tuber (Figure 1b) with also progressively increased from $6 \%$ up to $35 \%$, six months after storage. Based on disease incidence, the percentage of infected tubers expanded faster during the first half of the storage period, reaching $85 \%$ by the end of the third month of storage (Figure 1c). During the second half of the storage period, the percentage of infected tubers slowly increased from $85 \%$ to $95 \%$, i.e. a $10 \%$ increase during the last three-month period against roughly a $60 \%$ increase during the first three months of the storage period.

Like disease severity and incidence, $H$. solani spore populations increased over time in all potato storage sheds. Nevertheless, spore populations followed no consistent pattern, exhibiting multiple and variable peaks and drops (Figure 2). Moreover, spore populations showed very large variability among storage sheds, which can be inferred by the large standard errors of the means (SE).

Temperature, humidity and ventilation play decisive roles in $H$. solani infections. Silver scurf often develops if tubers are kept at high relative humidity and slightly cool temperature. Relative humidity of $90 \%$ or higher combined with temperature above $3^{\circ} \mathrm{C}$ are very suitable conditions for $H$. solani to infect and colonize available healthy tissue during the storage period (Lennard, 1980; Hooker, 1981). Under favourable conditions, ten-day-old lesions of $H$. solani are ready to produce and release new spores (Heiny \& McIntyre, 1983). This scenario apparently occurs in Tulelake potato storage sheds because silver scurf incidence and severity increased over time in all studied sheds (Figures 1). These results are consistent with other research that has described silver scurf with two-distinct phases: a field phase during which disease severity is very mild and a storage phase in which severity often rises due to recurrent $H$. solani cycles (Jellis \& Taylor, 1977; Lennard, 1980; Adams et al., 1985).

In contrast to the high levels of disease severity following storage, silver scurf severity is generally very mild at harvest time (Table 2; Figure 1). Therefore, new infections of $H$. solani must occur to account for the increase in disease progress during storage. Spore populations observed throughout the storage period (Figure 2) fit into this hypothesis. Thus, H. solani conidia moving through potato piles are very likely to land on healthy tubers or uninfected surfaces of already infected tubers and ultimately give rise to new infections. Studies conducted by Rodriguez et al. (1996), in which they placed pathogen-free minitubers in commercial potato sheds, showed that $H$. solani is able to spread and cause further infections during the storage period.

Spore populations often fluctuated during the storage period as if $H$. solani lesions went through intermittent spore production cycles (Figure 3 ). We should, however, be aware that spores are dislodged and released within commercial storage, which is the result of ventilation systems blowing air throughout potato piles, or tubers being moved or handled for grading or shipping. This irregular and somewhat forced process of releasing spores might account for spore population fluctuations as opposed to an intermittent pattern of lesion sporulation. If it is true that spore release 
is somehow forced by storage conditions, we can also speculate that a proportion of the spores may consist of immature conidia. This interesting epidemiological aspect should be an object of future investigation, the results of which might help explain the differences in disease severity among sheds with identical storage conditions and amount of initial inoculum.

Since potato storage conditions in Brazil are almost identical to those used in California and $H$. solani is often detected in imported lots of seed tubers, it seems very unusual that silver scurf has not yet caused any significant losses to the Brazilian potato industry (Reifschneider, 1987; Souza Dias \& Iamauti, 1997). This could be explained by the fact that there is no tradition of storing potato for long periods in Brazil, since it is essential for $H$. solani to go through several cycles during storage in order to compromise potato tubers, as demonstrated by our results in California.

Absence of resistant cultivars and the appearance of fungicide resistant isolates of $H$. solani have considerably complicated the control of silver scurf (Rodriguez et al., 1995; Errampalli et al., 2001; Merida \& Loria, 1994b; Cunha \& Rizzo, 2003). Integrated approaches will be required to manage this disease. Our results support the idea that potato growers should combine several control practices during the growing season and storage period seeking to reduce the abilities of $H$. solani to survive and spread to healthy tubers.

\section{ACKNOWLEDGMENTS}

The senior author is grateful to the Brazilian Ministry of Education (CAPES) for sponsoring his Ph.D. studies. The research was partially funded by the California Potato Research Advisory Board. We also thank Dr. R. Michael Davis and Dr. Thomas Gordon for their suggestions and assistance with the manuscript and Donald Kirby for potato storage and sampling.

\section{LITERATURE CITED}

ADAMS, M.J.; HIDE, G.A.; LAPWOOD, D.A. Sampling potatoes for the incidence of tuber diseases and levels of inoculum. Annals of Applied Biology v.107, n.2, p.189-203, 1985.

ALCORN, J.L. The taxonomy of "Helminthosporium" species. Annual Review of Phytopathology v.26, p.37-56, 1988.

ALEXOPOULOS, C.J.; MIMS, C.W.; BLACKWELL, M.M. Introductory Mycology. $4^{\text {th }}$ ed. New York, John Wiley \& Sons, 1996. 869 p. ANONYMOUS. Operating intructions for the rotorod sampler. Minnetonka, Sampling Tecnology, Inc.: 15 .

BAINS, P.S.; BISHT, V.S.; BENARD, D.A. Soil survival and thiabendazole sensitivity of Helminthosporium solani isolates from Alberta, Canada. Potato Research v.39, n.1, p.23-30, 1996. BARNETT, H.L.; HUNTER, B.B. Illustrated Genera of Imperfect Fungi. $4^{\text {th }}$ ed. St. Paul, The American Phytopathology Society, 1988. 218 p. CUNHA, M.G.; RIZZO, D.M. "Development of fungicide cross resistance in Helminthosporium solani populations from California." Plant Disease v.87, n.7, p.798-803., 2003.

DANOSKY, E.C. Annual report of Tulelake irrigation district. Tulelake, Tulelake Irrigation District: 24 p. 1995.

DHINGRA, O.D.; SINCLAIR, J.B. Basic Plant Pathology Methods. $2^{\text {nd }}$ ed. Boca Raton, Lewis, 1995. 434 p.

ELLIS, M.B. Helminthosporium solani. Descriptions of Pathogenic Fungi and Bacteria. Kew, Commonwealth Mycological Institute: 166. 1968.

ELLIS, M.B. Dematiaceous Hyphomycetes. Kew, Commonwealth Mycological Institute: 507. 1976. ELSON, M.K.; SCHISLER, D.A.; JACKSON, M.A. Carbon-to-nitrogen ratio, carbon concentration, and amino acid composition of growth media influence conidiation of Helminthosporium solani. Mycologia, v.90, n.3, p.406-413., 1998.

ERRAMPALLI, D.; SAUNDERS, J.M.; HOLLEY, J.D. Emergence of silver scurf (Helminthosporium solani) as an economically important disease of potato. Plant Patholology v.50, p.141-153., 2001.

FIRMAN, D.M.; ALLEN, E.J. Transmission of Helminthosporium solani from potato seed tubers and effects of soil conditions, seed inoculum and seed physiology on silver scurf disease. Journal of Agricultural Science, v.124, n.2, p.219-234., 1995.
FRAZIER, M.J.; SHETTY, K.K.; KLEINKOPF, G.E.; NOLTE, P. Management of silver scurf (Helminthosporium solani) with fungicide seed treatments and storage practices. American Journal of Potato Research, v.75, n.3, p.129-135., 1998.

HEINY, D.K.; MCINTYRE, G.A. Helminthosporium solani Dur. \& Mont. development on potato periderm. America Potato Journa,1 v.60, p. 773-789, 1983.

HOOKER, W.J. Compedium of Potato Disease. Minnesota, American Phytopatological Society, 1981. 125 p.

HUNGER, R.M.; MCINTYRE, G.A. Occurrence, development and losses associated with silver scurf and black dot on Colorado potatoes. America Potato Journal, v.56, p.289-306, 1979.

JEGER, M.J.; HIDE, G.A.; BOOGERT, P.V.D.; TERMORSHUIZEN, A.J.; BAARLEN, P.V.; VAN DEN BOOGERT, P.; VAN BAARLEN, P. Pathology and control of soil-borne fungal pathogens of potato. Potato Research, v.39, p.437469, 1996.

JELLIS, G.J.; TAYLOR, G.S. The development of silver scurf (Helminthosporium solani) disease of potato. Annals of Applied-Biology, v.86, n.1, p.19-28, 1977.

LENNARD, J.H. Factors affecting the development of silver scurf (Helminthosporium solani) on potato tubers. Plant Pathology, v.29,n.2, p.87-92, 1980.

MERIDA, C.L.; LORIA, R. Comparison of thiabendazole-sensitive and -resistant Helminthosporium solani isolates from New York. Plant Disease, v.78, n.2, p.187-192, 1994.

MERIDA, C.L.; LORIA, R. Survival of Helminthosporium solani in soil and in vitro colonization of senescent plant tissue. American Potato Journal, v.71, n.9, p.591-598., 1994.

REIFSCHNEIDER, F.B. Produção de batata. Brasília, Linha Gráfica, 1987. 239 p.

RODRIGUEZ, D.A.; SECOR, G.A.; GUDMESTAD, N.C.; GRAFTON, K. Screening tuber-bearing Solanum species for resistance to Helminthosporium solani. American Potato Journal, v.72, n.11, p.669-679, 1995.

RODRIGUEZ, D.A.; SECOR, G.A; GUDMESTAD, N.C; FRANCL, L.J. Sporulation of Helminthosporium solani and infection of potato tubers in seed and commercial storages. Plant Disease, v.80, n.9, p.1063-1070, 1996.

SECOR, G.A.; GUDMESTAD, N.C. Managing fungal diseases of potato. Canadian Journal of Plant Pathology, v.21, n.3, p.213-221, 1999.

SOUZA DIAS, J.A.C; IAMAUTI, M.T. Doenças da batateira. In: KIMATI, H; AMORIN, L.; BERGAMIN FILHO, A.; CAMARGO, L.E.A.; REZENDE, J.A.M. Manual de fitopatologia doenças de plantas cultivadas. $2^{\text {nd }}$ ed. São Paulo. Agronômica Ceres, 1997. 137-164 p. 